\title{
UTILIZATION OF RUBBER POWDER OF WASTE TYRES IN FOAM CONCRETE
}

\author{
MEHRANI Seengar Ali a , BHATTI Imtiaz Ali ${ }^{\text {b }}$, BHATTI Nabi Bux ${ }^{\text {c }}$, JHATIAL Ashfaque \\ Ahmed ${ }^{d}$, LOHAR Mouzzam Ali ${ }^{d}$
}

${ }^{a}$ Quaid-e-Awam University of Engineering, Science and Technology, Nawabshah, Sindh, Pakistan

${ }^{*}$ baculty of Civil and Environmental Engineering, Universiti Tun Hussein Onn Malaysia Parit Raja, Johor Malaysia, e-mail: engrimtiaz290@gmail.com

${ }^{c}$ U.S.-Pakistan Centre for Advanced Studies in Water Mehran University of Engineering \& Technology, Sindh, Pakistan

${ }^{\mathrm{d}}$ Mehran University of Engineering \& Technology, Shaheed Zulfiqar Ali Bhutto Campus, Khairpur Mir's, Sindh, Pakistan

Received: 28.03.2019 / Accepted: 06.04.2019 / Revised: 01.05.2019 / Available online: 31.05.2019

DOI: 10.2478/jaes-2019-0011

KEY WORDS: Foam Concrete, Waste Tyres, Rubber Powder, Plasticizer, Compressive and Tensile Strength.

\begin{abstract}
:
Foam concrete or light concrete has become increasingly recognizable in commercial and construction field. Foam concrete is not just light in its weight but also light in cost, as there is no coarse aggregate needed in its production. Application of foam concrete is limited due to the fact that it is not as strong as conventional concrete in terms of strength and rigidness. Therefore, this study is to investigate the potential of foam concrete incorporating with rubber powder of waste tire and admixture as an additive material to improve its strength and workability. Thus, the use of rubber powder in this study could enhance the strength by filling the voids in foam concrete. The amount of rubber powder added as additive in foam concrete is $0 \%, 5 \%, 10 \%, 15 \%$ and $20 \%$ respectively. The amount of plasticizers used is limited to less than $0.4 \%$ to the weight of cement. The mix design was set to achieve density of $1800 \mathrm{~kg} / \mathrm{m} 3$. The workability of foam concrete is decreasing as the percentage of rubber power was increasing. The foam concrete containing 5\% of rubber powder has highest compressive strength with value of $20.6 \mathrm{MPa}$ for 7 days water curing and $22.3 \mathrm{MPa}$ for 28 days water curing. Significantly showing an increase of $1.7 \mathrm{MPa}$. The highest value of tensile strength for both air curing 7 and 28 days are $1.86 \mathrm{MPa}$ and $1.97 \mathrm{MPa}$ also held by $3 \%$ of rubber powder mix. As a conclusion the optimum rubber powder content to be used in foam concrete is $5 \%$ that gives the highest results in terms of workability and strength.
\end{abstract}

\section{INTRODUCTION}

Foam concrete is the mixture of cement, fine aggregate usually sand, water and special type of foam. When this mixture hardened results in a strong light weight concrete. The density of foam concrete is determined on basis of cement and sand. Foam concrete is both water and fire resistant. It possesses thermal insulation properties and high impact air borne sound. Form concrete is like conventional concrete as it uses same ingredients. However, form concrete differs from normal concrete in that use of aggregates. The application of foam concrete is limited due to lack of strength as compared to conventional concrete. In order to make the world better place to live on, research and new studies were carried out by using excess of waste material from the industry. Typical wastes that were used came from fly ash, palm oil fuel ash, glass and plastic. The usage of different types of materials is aiming to increase the strength of foam concrete in terms of flexural strength, and in the meantime reducing the mass waste material produced by the industry. Rapid growth in automobile industry and increasing uses of vehicles, production of tyre is also increased which generates waste tyre rubber (Thakrele, M. H., 2014) (Alsaleh et al.,2014). Numerous researches on foam concrete had been carried out and only handfuls of them are generalizing in rubber as their significant of study. During the year of 2015, there are estimated around 335,000,000 vehicles registered all around the world and this ratio of registering the vehicles is increasing with the rate of $16 \%$ to $18 \%$ every year. According to (G.B. Sekhar, 2014) every year 1.7 billion new tyres are produced and over 1 billion waste tyres are generated every year. The usage of waste materials has becoming popular amongst the researchers in foam concrete as additive and filler (Abd et al., 2017) by increasing the strength but decreasing the workability of form concrete. This problem is overcome by adding the super plasticizer in foam concrete mixture. Super plasticizer is function as to increase the workability by decreases the spread ability of foam concrete mixture while

\footnotetext{
* Corresponding author: Imtiaz Ali Bhatti, e-mail: Engrimtiaz290@gmail.com
} 
doing the slump cone inverted test. Lack on strength in foam concrete has limited the application in construction field. Rubber powder has become potential material to apply in foam concrete to increase the strength by filling the voids in foam concrete hence the objectives of this study are to check out the workability of foam concrete containing rubber powder of waste tire, measure the compressive and tensile strength of foam concrete containing rubber power and find the optimum content of rubber powder used in foam concrete.

\section{LITERATURE REVIEW}

Originally foam concrete was generated in 1923 for the purpose to serve as insulation material. (Valore RC 1954) presented the first comprehensive review on foam concrete. Later on, the review on foam concrete treatment was given by Rudnai $G$ in 1963. Significant improvement in foam concrete are seen over past 20 years in production equipment and better quality that enable the use of foam concrete on large scale.

The first utilization of foam concrete started from UK in 1980's at the Falkirk railway tunnel project of Scotland. Around $4500 \mathrm{~m}^{3}$ of $1100 \mathrm{~kg} / \mathrm{m}^{3}$ density concrete was placed in space surrounding the tunnel and later $70,000 \mathrm{~m}^{3}$ of $500 \mathrm{~kg} / \mathrm{m}^{3}$ density concrete was used drainage and sewerage pipes and cable in the road foundation at canary wharf in London. Today's era utilization of foam concrete (Figure 1) has become famous significantly because of light weight, effective thermal insulation \& sound insulation this is the reason that nowadays it is widely used in more than 50 countries (Hsi, J.et al., 2005).

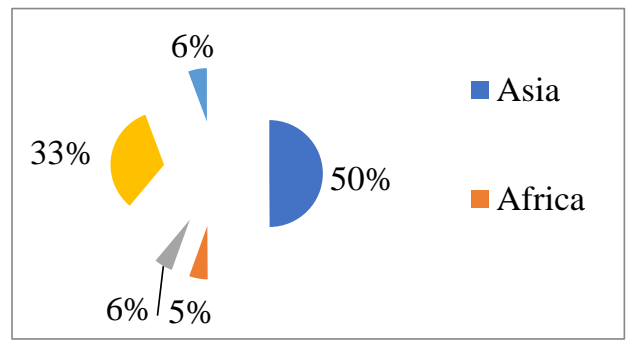

Figure 1. Utilization of Foam Concrete

\subsection{Application of Foam Concrete}

Now as days foam concrete are widely used in structural and construction field of civil engineering. It is now a wellestablished material in voids filling and highway repairing (Hsi, J.et al., 2005). Nowadays high density of foam concrete was used in structural application while low density concrete was used as cavity filling and insulation. Other applications of foam concrete include production of lightweight blocks and precast panels, fire insulation, thermal and acoustic insulation. Furthermore, due to flow ability characteristic, it is an excellent material for voids for example old sewers, storage tanks, basements, ducts and voids under roadway by cliff of heavy rains and snow fall (Bindiganavile et al., 2008). Uses of foamed concrete reduced the demand of primary aggregates which is thereby enhancing sustainability. Foam concrete is also beginning to be used in range of light weight, semi-structural application for example bridge abutments, floor and roof screeding, where the higher strengths is required (Narayanan et al., 2000). Table 1 shows the application of foam concrete at different place (Namsone et. al. 2017).

Table 1. Application of foam concrete

\begin{tabular}{|c|l|}
\hline Location/ Place & \multicolumn{1}{|c|}{ Application } \\
\hline $\begin{array}{c}\text { Northwest } \\
\text { Highway }\end{array}$ & $\begin{array}{l}\text { More than } 13,000 \text { cubic meter of Foam concrete was utilized of } \\
\text { density } 410 \mathrm{~kg} / \mathrm{m}^{3}\end{array}$ \\
\hline $\begin{array}{c}\text { The central } \\
\text { road, } \\
\text { Schaumburg, } \\
\text { Illinois }\end{array}$ & $\begin{array}{l}\text { Reconstructed at full depth of a four-lane road with drainage } \\
\text { advances and installation of curb and gutter. The general contractor } \\
\text { proposed a combination of } 900 \mathrm{~mm} \text { thick layer of } 400 \mathrm{~kg} / \mathrm{m}^{3} \text { and } \\
\text { 600mm layer of 500kg/ } \mathrm{m}^{3} \text { foam concrete }\end{array}$ \\
\hline $\begin{array}{c}\text { Chicago's } \\
\text { O'Hare } \\
\text { International } \\
\text { Airport }\end{array}$ & $\begin{array}{l}\text { Foam concrete was used to construct } 8.5 \mathrm{~m} \text { wide and } 3.04 \text { thick } \\
\text { spread footing to provide the required load reduction over } 883.87 \\
\text { m long stretch of water main to support a minimal amount of soil } \\
\text { cover placed on the top of the spread footing }\end{array}$ \\
\hline
\end{tabular}

According of report Forrest M. (2014), with the use of foam concrete thermal conductivity if building is reduced and Researchers at King Abdul-Aziz City for Science and Technology (KACST) have proved that buildings of foam concrete with a thickness of 150 millimeters can withstand flames for four hours at a temperature of up to 12,00 degrees Celsius.

\section{METHODOLOGY}

The wastes are abundantly available and have reached a level that severely threats the environment. Therefore, it is great need to find useful applications of these waste materials. It contains all details procedure of methodology, sample preparation, design mix and number of samples. The details of test on foam concrete such as inverted slump cone test, compression and splitting tensile tests are taken into account.

\subsection{Sample Preparation}

Preparation of sample started with the determination of the total amount of material needed for this research, which are cement sand, water foaming agent, rubber and plasticizer. Cube mould with dimension of $100 \mathrm{mmx} 100 \mathrm{~mm} \times 100 \mathrm{~mm}$ (Length, width and height) was used for compressive strength test and cylindrical mould with size of $150 \mathrm{~mm} \times 300 \mathrm{~mm}$ (diameter and height) was for splitting tensile strength test with water cement ratio aspect of 0.45 . Total amount of specimen for both compressive and splitting tensile test can be referred to table 2 below.

Table 2. Samples for Compressive \& Tensile Test

\begin{tabular}{|l|l|l|l|l|}
\hline \multicolumn{1}{|c|}{ Test } & \multicolumn{2}{c|}{ Compressive test } & \multicolumn{2}{c|}{ Tensile test } \\
\hline Rubber Content (\%) & 7 days & 28 days & 7 days & 28 days \\
\hline 0 & 3 & 3 & 3 & 3 \\
\hline 5 & 3 & 3 & 3 & 3 \\
\hline 10 & 3 & 3 & 3 & 3 \\
\hline 15 & 3 & 3 & 3 & 3 \\
\hline 20 & 3 & 3 & 3 & 3 \\
\hline Total & 30 cylinders & 30 cylinders \\
\hline
\end{tabular}


3.1.1 Mix Design: Density of foam concrete achieved was $1800 \mathrm{~kg} / \mathrm{m}^{3}$. Table 3 shows the concrete mix design for foamed concrete with water cement ration 0.45 and wastage of material is added $5 \%$.

Table 3. Mix Design for foam concrete

\begin{tabular}{|c|c|c|c|c|c|}
\hline Ratio & $\begin{array}{c}\text { Cement } \\
(\mathrm{Kg})\end{array}$ & $\begin{array}{c}\text { Sand } \\
(\mathrm{Kg})\end{array}$ & $\begin{array}{c}\mathrm{H}_{2} \mathrm{O} \\
(\mathrm{Kg})\end{array}$ & $\begin{array}{c}\text { Rubber } \\
\text { content }(\mathrm{Kg})\end{array}$ & $\begin{array}{c}\text { Super plasticizer } \\
(\mathrm{Kg})\end{array}$ \\
\hline $1: 2$ & 10.96 & 21.92 & 6.85 & $0(0 \%)$ & 0 \\
\hline $1: 2$ & 10.96 & 21.92 & 6.85 & $1.9(5 \%)$ & 0.06 \\
\hline $1: 2$ & 10.96 & 21.92 & 6.85 & $3.8(10 \%)$ & 0.06 \\
\hline $1: 2$ & 10.96 & 21.92 & 6.85 & $5.7(15 \%)$ & 0.06 \\
\hline $1: 2$ & 10.96 & 21.92 & 6.85 & $7.6(20 \%)$ & 0.06 \\
\hline
\end{tabular}

\subsection{Material}

Material used in preparation of foam concrete were cement, sand, water, foam agent, rubber powder and super plasticizer. Rubber powder of waste tyres which is the main material for this study were initially were collected to one place and burnt and then sieved from for uniform size and then added into foam concrete mixture. Details of material what we're being used in this study are follows.

3.2.1 Cement: The type of cement used for producing the foam concrete in this study is Ordinary Portland cement (OPC). The function of using this cement is to bind the fine aggregates and fill the voids.

3.2.2 Sand: Sand is one of the materials that need to be added into mixture. Sand functions as filler and increases the binding effect. However, the sand used was dry sand which was passed through $2.0 \mathrm{~mm}$ Sieve Size.

3.2.3 Water: Drinkable water was used in mixing the foam concrete. Power of Hydrogen $(\mathrm{PH})$ value of water was recorded as 6.5 .

3.2.4 Foaming Agent: Foaming agent (constro foam) was used in this study. The ratio of foaming agent to water being used was 1:20. Foam will be produced by using generator foaming agent.

3.2.5 Rubber: The percentage of rubber used in this study is $0 \%, 5 \%, 10 \%, 15 \%$ and $20 \%$ of weight of mixtures. First rubber was collected to one place and burnt as shown in figure 2 . Figure 3 shows that after burning some residue called rubber power is generated than rubber was being sieved first to ensure the uniform particle size.

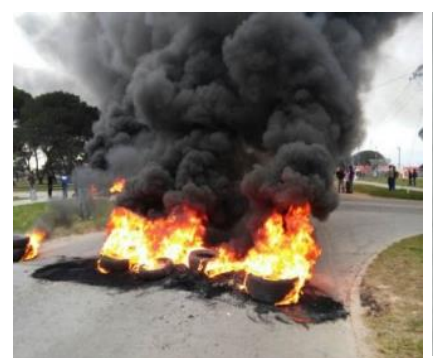

Figure 2. Collected tyres are burnt

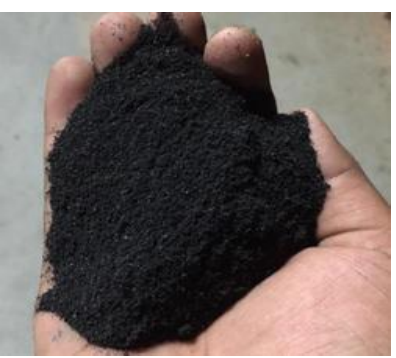

Figure 3. Rubber power
The size of sieve used were $5.0 \mathrm{~mm}, 2.26 \mathrm{~mm}, 1.18 \mathrm{~mm}, 0.60$ $\mathrm{mm}, 0.30 \mathrm{~mm}$ and $0.075 \mathrm{~mm}$ and weight of $500 \mathrm{~g}, 450 \mathrm{~g}, 400 \mathrm{~g}$, $350 \mathrm{~g}$. Weight of sieve size ranging from $0.30 \mathrm{~mm}$ to $0.075 \mathrm{~mm}$ was $350 \mathrm{~g}$ respectively. Total mass of $1700 \mathrm{~g}$ of rubber powder was used for sieving process. On sieve size of $5.0 \mathrm{~mm} 99.7 \%$ of rubber passed only $0.3 \%$ of material was retained, on sieve size of $2.26 \mathrm{~mm} 65 \%$ was passed only $35 \%$ of material was retained, on sieve size of $1.18 \mathrm{~mm}$, the data collected shows that $563.4 \mathrm{~g}$ of rubber was retained and fourth level sieve size of $0.60 \mathrm{~mm}$ stated that only $67 \mathrm{~g}$ of rubber retained which is $6.7 \%$ and no passing. Meanwhile for sieve sizes of $0.3 \mathrm{~mm}$ and $0.075 \mathrm{~mm}$ no retained and passing were collected. Rubber retained from $1.18 \mathrm{~mm}$ sieve is used for the mix.

3.2.6 Superplasticizers: It is reported that the plasticizer should not be commonly used in foam concrete unless the amount is limited less than $0.4 \%$ by weight of cement. It's is to improve the workability for the case of low water cement ratio.

\section{ANALYSIS}

The data gained were used to analyze and summarize the relevant studies to ensure the objectives and a goal of this research study has reached in accordance with what has been planned. Hence the first objective of this study was to check out the workability of foam concrete using rubber powder.

\subsection{Workability}

To achieve this objective, there were total 5 batch of foam concrete with rubber powder and plasticizer. Among of 5 batches, there is different percentage of rubber mixing with foam concrete. Testing were done by using inverted slump cone test table 4 shows the workability test results for all 5 batch types of foam concrete.

Table 4. Foam Concrete Workability

\begin{tabular}{|c|c|}
\hline Foam concrete Mixture & Average Slump Flow $(\mathrm{cm})$ \\
\hline A. Normal Foam Concrete with $0 \%$ rubber powder & 57 \\
\hline B. Foam concrete with $5 \%$ rubber powder & 49 \\
\hline C. Foam concrete with $10 \%$ rubber powder & 44 \\
\hline D. Foam concrete with $15 \%$ rubber powder & 39 \\
\hline E. Foam concrete with $20 \%$ rubber powder & 31 \\
\hline
\end{tabular}

\subsection{Compressive Strength Test}

The compressive test is the common method conducted to obtain the strength of foamed concrete. Types of samples used for this specific test is in a form of cubical shape. The compressive test was conducted on 7 days and 28 days of concrete curing that its time needed for a concrete to be completely matured and to obtain its optimum concrete strength (Table 5). 
Table 5. Average compressive strength test results

\begin{tabular}{|l|c|c|}
\hline \multicolumn{1}{|c|}{ Foam concrete mixture } & $\begin{array}{c}7 \text { days compressive } \\
\text { strength (Ave) }\end{array}$ & $\begin{array}{c}28 \text { days compressive } \\
\text { strength (Ave) }\end{array}$ \\
\hline $\begin{array}{l}\text { A. Normal Foam Concrete } \\
\text { with 0\% rubber powder }\end{array}$ & 9.16 & 11.84 \\
\hline $\begin{array}{l}\text { B. Foam concrete } \\
\text { with 5\% rubber powder }\end{array}$ & 15.80 & 17.15 \\
\hline $\begin{array}{l}\text { C. Foam concrete } \\
\text { with } 10 \% \text { rubber powder }\end{array}$ & 14.70 & 15.90 \\
\hline $\begin{array}{l}\text { D. Foam concrete } \\
\text { with } 15 \% \text { rubber powder }\end{array}$ & 7.30 & 10.10 \\
\hline $\begin{array}{l}\text { E. Foam concrete } \\
\text { with } 20 \% \text { rubber powder }\end{array}$ & 4.35 & 5.70 \\
\hline
\end{tabular}

It is seen that the highest compressive strength of foam concrete is with $5 \%$ of rubber powder mixture that shows the highest strength compared to other specimen at the same of 7 days curing with 15.4 MPa. However, the strength of foam concrete containing rubber powder decreased as the percentage of rubber increased from $10 \%$ to $20 \%$. The sample of foam concrete with $20 \%$ rubber powder showed the lowest strength obtained with value of $4.35 \mathrm{MPa}$. Even though the strength decreases as the percentage of powder increases.

\subsection{Tensile Strength Test}

Splitting tensile strength test was conducted on the same machine as were conducted for compressive strength test. Only thing that differs is the samples of this test are cylinder in shape and were put horizontally on the base plate of compressive test machine. Table 6 shows the strength results for 7 days and 28 days of foam concrete.

Table 6. Average tensile strength test results

\begin{tabular}{|l|c|c|}
\hline \multicolumn{1}{|c|}{ Foam concrete mixture } & $\begin{array}{c}7 \text { days tensile } \\
\text { strength (Ave) }\end{array}$ & $\begin{array}{c}28 \text { days tensile } \\
\text { strength (Ave) }\end{array}$ \\
\hline $\begin{array}{l}\text { A. Normal Foam Concrete with } \\
\text { 0\% rubber powder }\end{array}$ & 1.35 & 1.42 \\
\hline $\begin{array}{l}\text { B. Foam concrete } \\
\text { with 5\% rubber powder }\end{array}$ & 1.48 & 1.55 \\
\hline $\begin{array}{l}\text { C. Foam concrete } \\
\text { with 10\% rubber powder }\end{array}$ & 1.32 & 1.45 \\
\hline $\begin{array}{l}\text { D. Foam concrete } \\
\text { with } 15 \% \text { rubber powder }\end{array}$ & 1.02 & 1.21 \\
\hline $\begin{array}{l}\text { F. Foam concrete } \\
\text { with } 20 \% \text { rubber powder }\end{array}$ & 0.62 & 0.54 \\
\hline
\end{tabular}

It can be said that the highest tensile strength achieved are from the foam concrete with $5 \%$ additional rubber powder resulting in $1.48 \mathrm{MPa}$ for 7 days. The graph declines right after $5 \%$ additional rubber powder and followed by $10 \%, 15 \%$ and $20 \%$ after reaching its peak of strength at $5 \%$ of rubber powder addition.

\section{CONCLUSION}

Results shows that samples with $5 \%$ addition of rubber powder can provide good mechanical strength for both tensile and compressive strength.
This research proves that the rubber powder of waste tyre is capable of being used as sustainable additive to foam concrete making as there is unlimited supply and also gives relatively good figures in mechanical performance, hence the utilization of waste tyres will beneficial to protect the environment.

\section{References:}

Forrest, M. (2014). "Overview of the World Rubber Recycling Market". Recycling and Re-Use of Waste Rubber, (Abril), 17-18.

"Recycled Rubber and Assessment of the Risks and Inhalation Exposure Ecopneus," 2016.

Oginni, F. (2015)."Continental Application of Foamed Concrete Technology: Lessons for Infrastructural Development in Africa". British Journal of Applied Science \& Technology, 5(4), 417-424. https://doi.org/10.9734/BJAST/2015/13063 .

Namsone E et. al. (2017). "The environmental impacts of foamed concrete production and exploitation". IOP Conference Series: Materials Science and Engineering, 251(1). https://doi.org/10.1088/1757-899X/251/1/012029.

Bindiganavile, V., \& Hoseini, M. (2008). "Foamed Concrete". Developments in the Formulation and Reinforcement of Concrete, (4586), 231-255.

Thakrele, M. H. (2014). "Experimental study on foam concrete". International Journal of Civil, Structural, Environmental and Infrastructure Engineering Research and Development, 4(1), 145-158.

Alsaleh, A., \& Sattler, M. L. (2014). "Waste Tire Pyrolysis: Influential Parameters and Product Properties". Current Sustainable/Renewable Energy Reports, 1(4), 129-135. https://doi.org/10.1007/s40518-014-0019-0.

Narayanan, N., \& Ramamurthy, K. (2000). "Structure and properties of aerated concrete: A review". Cement and Concrete Composites, 22(5), 321-329. https://doi.org/10.1016/S09589465(00)00016-0.

Abd, A. M., \& Abd, S. M. (2017). "Modelling the strength of lightweight foamed concrete using support vector machine (SVM)". Case Studies in Construction Materials, 6, 8-15. https://doi.org/10.1016/j.cscm.2016.11.002.

B. Sekhar (2014). "Tire Technology Expo in Proceedings of Cologne". Germany.

Valore RC. "Cellular cement part 2 physical properties". ACI J; 50: (36-817), (1954).

Rudnai G. "Light weight concretes". Budapest: Akademi Kiado, 1963.

Hsi, J. and Martin, J. (2005). "Soft Ground Treatment and Performance, Yelgun to Chinderah Freeway, New South Wales, Australia." In Ground Improvement-Case Histories, Elsevier Geo-Engineering Book Series, Volume 3, 563-599. 